\title{
The Ogaden War: Somali women's roles
}

\author{
Remco Van Hauwermeiren
}

Faculty of Arts and Philosophy, Ghent University, Belgium

\begin{abstract}
In 1977 Somalia invaded Ethiopia hoping to seize the Ogaden, an Ethiopian region predominantly inhabited by ethnic Somali. Histories of this event are rare and focus exclusively on the political and military aspects of the conflict. This is not surprising given the Cold War backdrop of the conflict. This article, however, shifts the focus away from the political towards the personal. Focus here is on the different roles Ogadeni women took up in the Somali-Ethiopian war, also known as the Ogaden war. Through interviews with former actors in the conflict it became clear that women occupied a range of roles in the war, varying from victims or care-givers to active participants in militias and front-line combat. In conflicts today, Somali women still retain many of these roles. Originally some Somalis did oppose this state of affairs, today most seem to have accepted the phenomenon of female actors in the Ogaden war, even though that approval can be linked with a political agenda. Both Ogadeeni and Somali women were active in the war, transcending Somali clan lines along the way. Accounts of the women interviewed illustrate the effects of their choice to participate in the Ogaden war.
\end{abstract}

Key words: Ogaden, Somalia, Ethiopia, gender, women's history

\section{Introduction}

The Ogaden war or Somali-Ethiopian war (July I977-March 1978$)^{1}$ was one of the largest inter-state wars in contemporary African history (Heirman, s.d.). The war was predominantly fought in the Ogaden region in eastern Ethiopia. This part of the Ethiopian plateau is mainly populated by Ogadeeni - literally 'those of the plateau' (Cerulli, I957) - a Somali 'sub clan' belonging to the large Daarood clan (Ibid.).

The Ogadeeni are a mostly nomadic people who herd camels, sheep and goats in a region westerners have referred to as 'a thousand miles of sand' (Young, 198I). The aridity of the region was no deterrent to the irredentist ambitions of Somali president Siad Barre (1969-I99I), who wanted to incorporate the Ogaden region into a Greater Somalia. In the early r 970 B Barre unofficially supported several Ogaden based militias such as the

The given timetable can never be more than just an estimate. The conflict in the Ogaden started in the Igth century and still continues today. Periods of violent conflict between rebels and the Ethiopian state alternated with periods of calm in which tensions were latent. Furthermore, since Somalia never officially declared war on Ethiopia there is no clear date at which the war broke out or when it ended. The dates used here are those that are most often used in the literature: July 1977 seems to be the start of more intense fighting. The end date, however, is more uncertain: May 1978 is often mentioned, but others use 1979. 
Western Somali Liberation Front (WSLF). Their task was to structurally weaken the Ethiopian forces in the Ogaden before the Somali army could invade Ethiopia in 1977. In the first couple of weeks of the war Somali troops were able to capture most of the Ogaden after which long and costly battles developed over the bigger cities such as Jijiga, Harer and Dire Dawa. Because the USSR and Cuba, originally supporters of Somalia, switched sides and allied themselves with Ethiopia, Somalia eventually lost the war and was forced to retreat back into its own territory. Thus the people living in the Ogaden desert were first overwhelmed by the WSLF${ }^{2}$, then by the Somali regular army and eventually by the avenging Ethiopian troops. It was not until I 988 that Somalia officially stopped supporting Somali militias who had continued to fight Ethiopian forces (Heirman, s.d.). However, fighting in the area resurfaced many times. In 1984 , the Ogaden National Liberation Front (ONLF) was established and they remain active in the region today, though they no longer fight for a Greater Somalia but for an independent Ogadeenia (M. Sherif, male, 27/04/20II). Until the mid-200o's the Islamist group Al-Ittihad al-Islamiya, later changing its name to the United Western Somali Liberation Front (UWSLF), was also active in the Ogaden (Harper, 2012; Monitoring Group on Somalia, 2008; M. Warsame, male, 15/03/201I).

So far, little research has been done on the motivations of the different actors in the war making histories of the conflict confusing. Historians and political scientists disagree on the exact geographical and temporal boundaries of the conflict, and the scale of the human cost is unknown. ${ }^{3}$ Even during the war itself, ambiguous signs were sent out through different media and it seemed that each group had its own idea on the purpose of the conflict. ${ }^{4}$ Here, the aim is to reach a better understanding of the Ogaden war by turning to a group of actors that is most often overlooked.

This research is based on interviews and discussions with people who lived through the war. Their accounts of events as they witnessed them will not constitute a conventional positivist historiography of the Ogaden war, but a narrative that is valuable because it shows the war as it was witnessed and remembered by those involved. I believe this perspective to be essential if we want to understand the real impact of the war.

This discussion of the Ogaden war focuses on the roles of women, for they are too often considered victims or, at best, passive actors in a conflict. They are rarely seen as active participants in war. This presumption is, however, based on a western ideal of gender models in which women are carers and men protectors. This model is no reality: 'We need recall only the tales of Herodotus and the more recent accounts of the amazons of Dahomey to realize that woman has shared in warfare - and with no less ferocity and cruelty than man' (De Beauvoir, 1979). Therefore this paper wishes to discuss the roles Somali women took up in the

3 There are no figures available on civilian casualties but according to Gebru Tareke (2000) the Ethiopian and Somali armies both lost over 6,100 troops. Ethiopia had over 10,500 members of personnel injured, Somalia over 2,400 .

4 According to some, referenda were to be organised in order to decide whether the Ogaden would become a part of Somalia or an independent state. ('Ogaden people to decide' 18/08/1977). 
Ogaden war, hoping to challenge existing gender ideas that still guide so many policy makers and researchers concerned with the Horn of Africa. Although this research had limited resources at its disposal (and is therefore likely to be incomplete) it aims to clear the mist around the Somali 'herstory' (Morgan, 1970) by asking what the roles of Somali women were in the official Somali army, the Western Somali Liberation Front, and the Ogaden National Liberation Front, as well as asking about those of civilian women in this conflict.

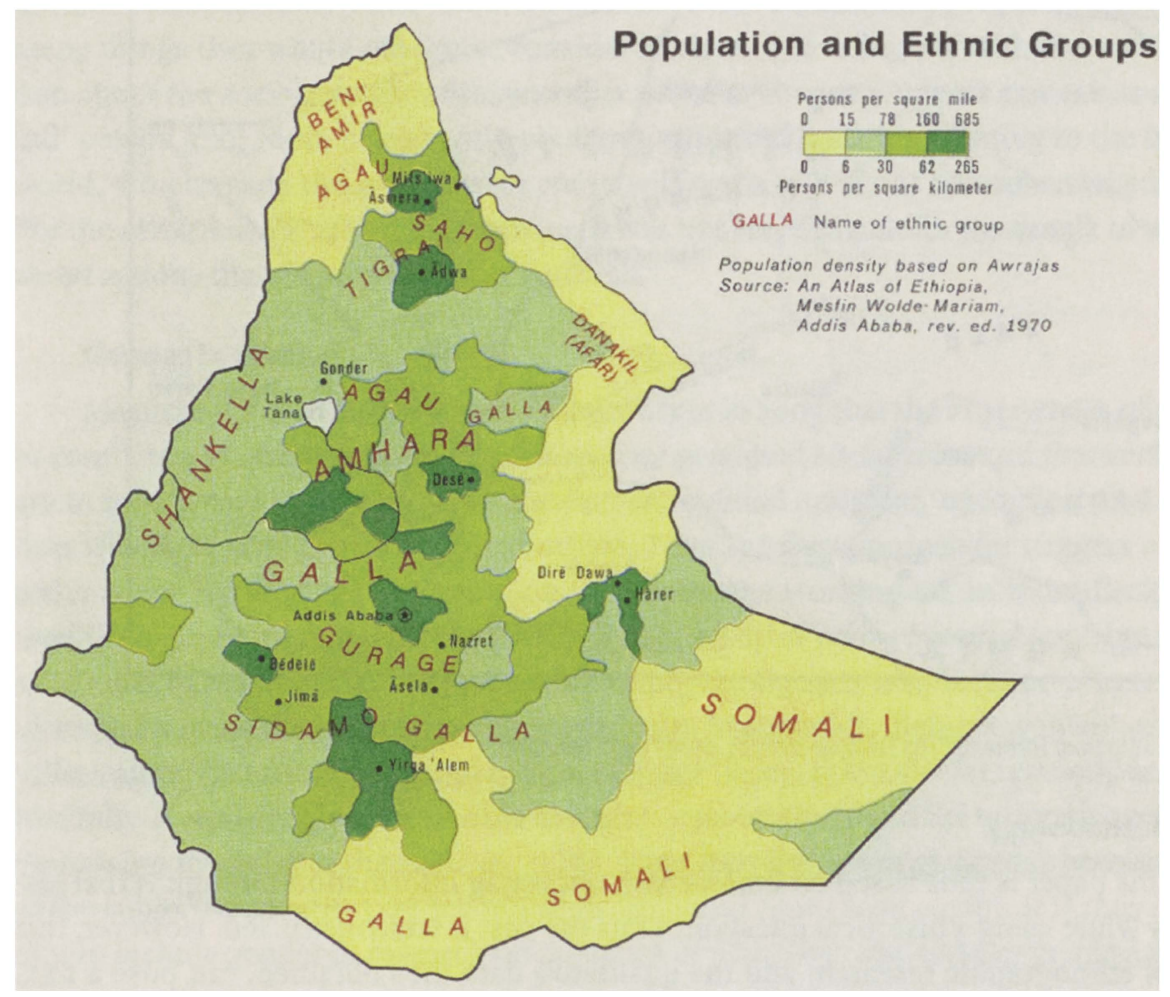

Figure 1: Map from lib.utexas.edu 


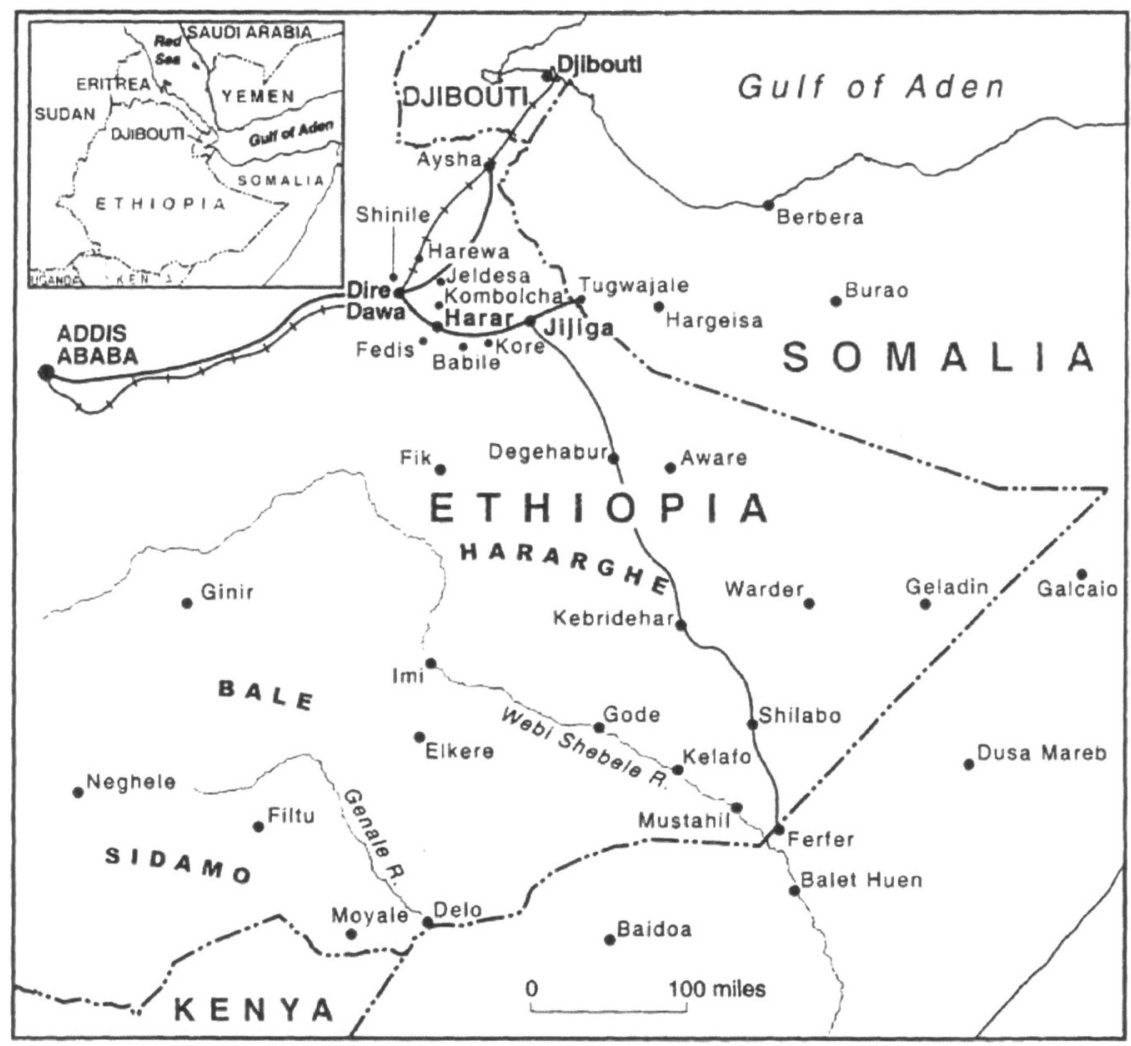

Figure 2: Map from Tareke G. "The Ethiopia-Somalia war of 1977 Revisited"

\section{Methodology}

This paper is thus based on oral history, obtaining information through verbal testimony while using a historical question. Thus the past is (re)constructed. However, this kind of ethnographic research, and the qualitative data thus obtained, can pose a risk. The interviewees already contextualised the discussed events, thereby creating an image of the past that is his or her own and fits his or her motives or bias. The oral history that will be produced here is therefore a product of its cultural and social context. It can be, therefore, difficult to verify certain claims. Yet, by comparing the different accounts of the different respondents, a more general image of this context can be achieved. By comparing these oral accounts with the few written sources and literature on this conflict new ideas could emerge.

For this article 18 people were interviewed in Kenya over a period of three months of fieldwork. In Belgium and the United Kingdom I had several informal talks with Somali refugees. The people interviewed included Somali men and women active in the WSLF or its youth movement, Somali men active in the Somali military, people who are or were active in the ONLF, members of the diaspora and civilians. These people came from dif- 
ferent socio-economic backgrounds: some of them were community leaders, others were uneducated, some were wealthy, most were poor. Most of these people were contacted through the network of two Nairobi based NGO's who wish to remain anonymous out of fear of the Ethiopian government. They were selected in such a way that different social strata were represented.

By using so-called 'semi-structured interviews' the ideas and conclusions resulting from the research were created during the interviews. These are illustrated with quotes from the interviewees. My own position as interviewer and researcher is an extremely important consideration in this research. Because I was an outsider, people had to explain many things they would otherwise consider obvious, providing me with more information about the social context of this conflict. Most of the respondents saw me as a 'neutral' person and, more importantly, someone who could tell "their" story to the outside world, which made the interviewees more willing to talk about controversial subjects. For the same reason, and to my surprise, it was not very difficult for me to talk to women about actions that disrupted gender patterns.

\section{Gender in conflict}

Mazurana, Raven-Roberts, and Parpart wrote in 2005 that the experiences of people in conflicts and afterwards are shaped by their gendered social roles and that such roles are in turn 'formed by cultural, social, economic and political conditions, expectations, and obligations within the family, community and nation'. Thus the focus on gender triggers a much wider scope for research. Working on gender means working on an inter-disciplinary level (Rosi Braidotti, 7/03/2012). Gender is thus a way of 'asking historical questions' (Scott, 2008) that have not been asked yet in discussing the Ogaden war. Yet Scott also reminds us to be aware of the uniqueness of gender roles in societies. 'Being a woman' or 'man' differs along historical and geographical settings (Riley, 1987). Social relations vary, just like 'cultural available symbols that evoke multiple... representations' and the normative concepts that assign meaning to them (Scott, I986). Even the ways in which gender becomes part of the subjective identity vary according to space and time (Scott, 1986 ). It is thus important to include gender in research on the Horn of Africa but also to keep in mind that we are not confronted with classic western gender concepts (Rosaldo, 1980; Okin, 1998). This being said, this text focuses more on women than it does on gender making the label "women's history" more appropriate. Conveniently, some claim that women's history has to precede, and create a base for, gender history (Wiesner-Hanks, 2008).

While this research hopes to challenge existing gender ideas, it does not claim that women are ignored when violent conflicts are discussed. On the contrary: many NGOs, researchers, and governments do pay attention to women in conflicts. However, they work on issues such as gender based violence, women as mothers, widows, and nurses: issues that perpetuate classic Western gender roles. When the involvement of women in conflict is recognized, they are seen as either victims or agents of peace. The fact that 'women and girls... play crucial roles in supporting and perpetuating violence' (Mazurana et al., 2005), is thus often ignored and women are predominantly portrayed 'as passive objects 
rather than subjects' (Macdonald, 2008). In brief: 'the presence of girl fighters has been continually ignored by the international community and neglected in academic writing. When girls have attracted attention, it has been purely as victims' (Macdonald, 2008). A dangerous and disturbing consequence here is the line that conflicts are described and explained via aggressive men only. Apart from an unfair allegation of guilt, this incorrect image of the aggressive (African) male has a strong influence on policy makers worldwide, and supports the western stereotype of the "helpless African women" as a strong symbol of victimhood, a basic idea in the aid industry (Macdonald, 2008). According to El-Bushra and Sahl (2005), the focus on women as peaceful beings has led many development agencies in Somalia to fail to 'capitalise on the wider changes [for women] which result from... war'.

This being said, it needs to be stressed that by focussing on the active roles women play in conflicts, this paper does not want to dismiss the suffering they experience, nor does it deny the fact that, like men, more women are victims then perpetrators in armed conflicts.

\section{Women in violent conflicts}

Comparative analyses are never easy, especially when respondents continue to stress the uniqueness of their situation. Mohamad A. (male, 14/03/2011), for example, insisted that the Ogaden war was much more lethal than the Eritrean war of independence, and an elderly anonymous lady (17/02/201I) could not understand the level of attention South Sudan receives, for she sees this as 'a much younger conflict with far fewer casualties'. However, when one is confronted with a limited number of sources, some nuanced comparisons can enrich the account and the arguments. 5 To prevent any generalisation on Africa, the following cases will extend beyond the African continent.

It is important to be clear that comparison is possible: girls and women have been fighting all over the world. In 2005 Mazurana et al. compiled a list of recent conflicts in which women had actively fought: 'Between 1990 and 2003 , girl soldiers were present in fighting forces and groups in at least fifty-four countries and participated in armed conflict in thirty-six of those countries'.

Page (1998) described the participation of women in the British colonial forces in East Africa. Lady Sidney Farrar, a so called FANY ${ }^{6}$ during the First World War, established the Women's Territorial Service which by the end of r940 included some 800 women. These women were active in the whole of East Africa and the Horn. They did not engage militarily in World War II but they occupied several logistic functions in dispatch, mail, and telephone services and staffed the ambulances 'held in readiness for casualties from Ethiopia' (Page, 1998). We shall see that Somali women occupied similar functions in the Somali-Ethiopian war. As World War II proceeded, the Women's Territorial Service took on additional duties such as catering, but also intelligence work in East Africa, Somalia, and other places within the British Empire (Page, 1998). 
Women also served 'in every capacity, including in front-line battle' for the Eritrean Liberation Front and they were trained in special training camps (Duffy, 1977). The Ethiopian army has also been working with women since r983 (Amnesty International, r99I).

In Sierra Leone women of all ages were prominent in the civil war (I99I-2002). Twenty-five per cent of the child soldiers, or eight per cent of the total number of fighters, were girls (Macdonald, 2008). According to Macdonald (2008) these Small Girls Units 'also committed a high level of atrocities'. Older girls and women were also active in the higher ranks of the military organisations of the NPLF and the RUF. Here women, like their male colleagues, had different tasks and roles; they were 'cooks, porters, wives, food producers and spies. Furthermore, nearly half of those interviewed... received basic military and weapons training' (Macdonald, 2008). The label of 'victim' that many of these girls received afterwards is challenged even further when it appears that many joined these groups voluntarily because fighting in the war offered them excitement, power, and material gains (Macdonald, 2008) and because it also offered relief from pressures at home, school or elsewhere (Brett and Specht, 2004).

In Mexico, women were active in the revolutions of the early 2oth century. Reséndez Fuentes (1995) describes how they were colonels in the different rebel armies, regular soldiers, nurses, caterers or prostitutes. There were wives giving moral support, spies, smugglers, messengers, and financiers. Women carried the equipment, foraged after the battles, smuggled arms and ammunition: 'No army of the revolution fought without women' (Reséndez Fuentes, 1995). Some women in the Mexican revolution were known for their horsemanship, cunning and intelligence, others for their discipline or their cruelty. In fact, in the first couple of years of the revolution, the imagination of the international public was captured by this 'image offemale soldiers' (Reséndez Fuentes, 1995). These Mexican women were in many aspects different from Somali women in the Ogaden war. Ogadeeni women were more than simply housewives following the battlefields, as seemed to be the case for most of the soldaderas in Mexico. Nor were they merely the wives or daughters of leading soldiers, as was the case with most of the Mexican female fighters. However it is the case, as we shall see in the next chapter, that the nurses of the WSLF in the Ogaden war displayed some similarities with the soldaderas who 'combed the ground for wounded soldiers [...] treated the injured on the spot, then transported them in ox carts to the nearest hospital.' (Reséndez Fuentes, 1995).

Thus the labels women receive as either advocates for peace and post conflict reconstruction or victims of war crimes are incomplete (Mazurana et al., 2005).

\section{Somali women in the Ogaden war}

According to El-Bushra and Sahl (2005) 'in traditional Somali warfare women and children were spared from violence'. However, this quotation can be challenged. First we can ask what 'tradition' really is. For example, one of the respondents claimed a rather different notion of 'tradition' stating that Somali women 'traditionally... didn't stay in the kitchen!' but have always been active in society, politics and struggles (M. Warsama, male, 15/03/20II). Perhaps the word 'traditional' does not refer to a reality but to an expectation people are 
supposed to live up to. Secondly and more importantly, this quotation serves the tradition of obscuring women's roles in armed conflicts and thus ignores a significant part of Somali history. Although very little is known on Somali women in conflict and even less has been written on the topic, it seems women have been politically and militarily active ever since the struggle for independence in Somalia. (Jama, I99I; M. Warsama, male, I5/03/20II). Furthermore, many of the respondents stated proudly that women were the backbone of the Ogaden war (M. Derrie \& Ugas, both male, I6/02/2011). The interviews conducted for this article made clear that women occupied a wide variety of positions and functions during the war, ranging from active fighting to a more symbolic role in the wartime discourse. Yet, when discussing the wartime roles of Somali women we should take care not to 'lump all women of the battlefield together' (Reséndez Fuentes, 1995). Every woman has a different story to tell and even though some of their experiences will be generalized here, we have to keep in mind that this article is based on a relatively small number of sources.

\section{Women in the WSLF}

Within the Western Somali Liberation Front, women had many different roles to play. As was the case in Sierra Leone, a few women were leaders in the organisation of the rebel front (M. Derrie, male, $16 / 02 / 2011$ ), with some even leading sub-units of the WSLF armed forces (M. Sherif, male, 27/04/20II). Considerably more women within the WSLF were fighters with a lower rank: 'Oh yes! They were fighting often! At that time, they are super armed' (M. Warsama, male, 15/03/20rI). Yet the number of female fighters was limited. One former WSLF fighter estimates that about five per cent of WSLF fighters at the front were women. Assuming that this is a reasonably accurate figure, we might estimate the number of female fighters in the Ogaden war. According to the Ethiopian government the WSLF had about 30,000 guerrilla fighters in its ranks just before the war (Adam Lockyer, 2006). Lockyer (2006) estimated that an additional 15,000 troops joined this force at the start of the war. A figure of 45,000 seems more realistic than the 400,000 the WSLF claimed in Time magazine ('Sticks, Stones and Rockets' 24/10/1977). Based on these rudimentary and unconfirmed sources we can estimate that around 2,250 female fighter were active in the Somali-Ethiopian war.

These women were living a hard life. Apart from the horrors of the battlefield, their daily lives were altered dramatically by the war. A woman who grew up in Mogadishu explained how big the difference was in lifestyle:

'[There are] snakes you are never used to it, there are a lot of people [wounded] by snake bites because there is no city, they sleep in the forest because they [are] hiding ... life was very hard. There is no houses, there is no place to sleep ... you have dried food so you will eat if you cannot that time. Sleeping, you have to sleep on the sand, there is no other place to sleep ... If you' re going to the bathroom, you have to go to the forest, there is no bathroom, towels, nothing. You not taking shower, even days, so ... it was very hard life.' (Fadumo M., female, 12/03/2011). 
A (male) soldier of the WSLF also tried to explain the impact of the spartan life of a rebel:

'It's a very hard life. ... Not the life of a human. ... When I come to be old, I remember that time is very hard. But when you're younger, you cannot feel it: you're just running. Bad food, bad life, bad place where you can sleep, you're very hungry sometimes, you don't have enough time to eat, you cannot get enough time to sleep.' (M. Ali, male, I4/03/2011).

The clothes they wore reflected their lifestyle and their priorities:

'Every nomad seems to carry a rock, a club or a knife. Some have antiquated rifles, and a few proudly display Soviet-made automatic weapons. They are dressed in rags for the most part, but are highly motivated.' ('Sticks, Stones and Rockets' 24/10/1977).

These fighters were constantly on the road together: moving from one front to another. Since both men and women were fighting, they were living closely together. In a society where the interaction between genders is highly regulated and a certain physical distance is expected to be maintained, this was not always an easy situation:

'Of course we, women, because of our religion, they always be separate from men. But not very distant. ... during the war, it's not same as when you are safe: ... but you are like a soldier... so of course there was sleep in the same area, but then you are not ... sleeping next to a man, you cannot do that, but in the same area.' (Fadumo M., female, 12/03/2011).

When a woman was injured, it was likely she was helped by a female nurse, but some were also treated by men. One respondent recounts the story of a woman who was fighting in the war and was shot in her hip. When a male nurse tried to help her, she refused for she wouldn't allow a man examining her thigh ( $\mathrm{H}$. Isse, male, 14/03/201I). Details such as this show how even the strongest women continued to respect the pervasive gender regulations of their society. The disruption of these everyday elements of life seemed as important to the informants as the cruelty of war.

Female fighters held powerful positions in the war since they were direct enemies of the Ethiopian forces, opposing and killing them just as men did. ( $\mathrm{H}$. Isse, male, 14/03/20II). Yet, this does not mean these women were not victimised. In battle women were wounded and killed, ${ }^{7}$ and like men, they suffered when they were taken prisoner by the Ethiopian soldiers who raped and/or killed them (M. Ali, male, I4/03/20II; M. Derrie \& Ugas, both male, I6/02/20II). In Somali society such sexual violence alienates the victim from her own social network (Gardner \& El Bushra, 2004). It 'involves an act of revenge aimed at humiliating and dishonoring a powerful and potentially threatening rival... [and the also a female fighter lost her life in the war. An elderly lady (17-02-2011) lost a niece who also fought for the WSLF in the war. 
rival is] ... supposed to break down under the grief and dishonour of the violation of his womenfolk' (emphasis by Haeri, 1995). Yet rape and sexual violence at the hands of military groups were not as common in the Somali-Ethiopian war as they are in the current conflicts in the Horn (El-Bushra \& Sahl, 2005). All informants emphasised the sexual violence in today's Ogaden, thereby downplaying sexual violence during the Ogaden war. Research on sexual violence during the Somali-Ethiopian war is therefore necessary in order to deepen our understanding of women's roles and actions.

Many more women within the WSLF were nurses who had to take care of wounded fighters. Most of them were volunteers from Somalia. There were different kinds of nurses within the WSLF, each working at a different stage (and place) in the process of treating wounded fighters. There were nurses who attended fighters from the moment they were wounded in battle. They had to be in the midst of the fight, providing first aid and bringing the wounded to the much safer field hospitals (often not much more than the shade of a tree). Here, patients were actually treated and when the wounds were too severe, were transferred to military hospitals in Somalia. Those who needed a lot of care but were not badly injured were often handed over to local families who took these soldiers in. A family could host up to 13 people for several months. Once their wounds had healed, many fighters returned to the battlefield (Fadumo M., female, 12/03/201I; Volunteer, female, r9/02/20II; M. Ali, male, 14/03/2011; Officer, male, II/04/2011).

Yet, these nurses are more than just caring women: all of them were armed, keeping a gun at their side at all times (M. Sherif, male, 27/04/201I). When we consider that the front-line nurses were side by side with the WSLF fighters, facing life-threatening situations on a daily basis and 'running after the soldiers who were fighting,' (Fadumo M., female, 12/03/2011) the divide between these nurses and the female fighters is blurred. Fadumo, a frontline nurse of the WSLF 'was injured [by] one of the Ethiopian soldiers, he had [a] bayonet, it's something like a knife. A strong one and they put in [my] shoulder. And [I] was wounded in that way.' (Fadumo M., female, 12/03/201I). The functions of these nurses extended beyond caring for wounded WSLF fighters. They had to bury those who died, mostly at the spot where they had fallen, and they also helped wounded civilians. Sometimes, they even helped civilian women deliver their babies. (Fadumo M., female, I2/03/20II). Their work earned them the respect of their brothers and sisters in arms: 'we help a lot of people ... we made a lot of friends ... because they were side by side to those actions.' (Fadumo M., female, I2/03/20II).

Most women in the WSLF occupied practical and logistical functions. Here a distinction needs to be made between those women mainly responsible for telecommunications within the military department of the WSLF and volunteers who provided the fighters at the frontline and in the camps (Volunteer, female, I9/02/2011).

The women working as communication experts were always with the fighting units, carrying their devices, weighing about $12 \mathrm{~kg}$, on their backs (H. Isse, male, 19/02/201I). These women were also armed at all times (M. Sherif, male, 27/04/20II). Their experiences are therefore much like those of the frontline nurses. 
There were also ' $a$ lot of women helping the military and helping the wounded people [...], giving them food, water, whatever they needed.' (Fadumo M., female, 12/03/2011). These women (there were almost no men doing these jobs) had to provide the people at the frontline with everything they needed but could not carry with them. They not only brought them food but also water, clothes, medicines, bandages, etc. (M. Ali, male, 14/03/20II). Some of these women had only one task: to carry water to the fighters, ensuring they had sufficient to drink, a crucial job in a war fought in such a hot and dry climate. Even though they were most often based in towns and small villages where the main units of the army were based, many of these women went to the frontline on a regular basis (M. Ali, male, I4/03/20II).

Women were also important for morale in the WSLF. They played a crucial role in the so-called danta, musical events, often performed in the evening that served to entertain the troops and lift their morale. Danta were always performed away from the front: while music was playing men and women danced and clapped their hands. Often elderly men blessed young fighters in order to motivate them. A danta, in short, served to lift the spirits of the fighters and other members of the WSLF. Women played a central role in this for they were singing and dancing, calling the fighters to keep up their fight (M. Ali, male, I4/03/20II). Most often these women were active in the WSLF as cooks, nurses or had a logistical function, but sometimes civilian women from the surrounding villages joined the danta. A former WSLF soldier tried to explain how exactly these danta were organized:

'So what we were doing, the ladies they are one line and men they come on one line, they stand in the night-time. They didn't do it in the daytime. They shake the hands and they're dancing ... The soldiers ... call our country we lost. [They addressed] the ladies "what do you want?" the men said. The ladies, they answer: ... "I wanna fight but I need arms and trees"... then they say "I will fight the frontline ... and I will burn ... the homes of the Ethiopians"... That's [what] they sing, the entertainment, on both sides. ... Some of them [the women who sing] were fighters and some of them came from the farmers and some of them, they came from the small towns ... some senior fighter ... they give [me] the danto, the cultural blessing, that's how it's called.' (M. Ali, male, I4/03/20II).

Fadumo, one of the respondents, remembers she performed a danta almost every night and that she was very popular amongst her colleagues: her songs and poetry were attractive and hopeful (Fadumo M., female, 12/03/2011). The songs that were sung are still popular today and one can easily collect a cd full of songs in any cd-printing shop in Eastleigh, Nairobi. However, very little is written on danta, and this is limited to the enactment: the dance moves and the music (or clapping) accompanying the dance (Abdullahi, 200I). Analyses on how danta could be a part of the process of constructing a collective historical memory could thus be a valuable replenishment of today's knowledge on Somali culture. Thorough and analytical studies on how ideas are expressed by the many different forms of dancing in Somalia could then give us a better understanding of the 
spread of political and historical constructs and the role women (as a crucial actor in any danta) hold herein. Especially since dancing is often seen as the ultimate personal expression and, as Morgan (1970) notes, 'the personal is political'.

Women in Somalia and the Somali army

Women were also important on the side of the Somali Republic. Habiba (female, $07 / 09 / 2010)$, a Somali refugee in Belgium, explained that Somali women were part of the 'democratic' republic of Somalia and thus 'equal in all aspects of life'. ${ }^{8}$ Therefore, they had to serve in the military too. She stated there were many women in the Somali army but they did not actually fight. There may have been the occasional involvement in combat when circumstance dictated, but women were mainly employed as drivers or cooks, in logistics and in other non-combat functions (Habiba, female, 07/09/2010). A former commander of the Somali army concurred when he said the official Somali troops did not use female fighters, even though the military had women in its ranks: Somali officers saw them as 'too weak to actually fight' in a war (Officer, male, Ir/04/2011).

In Somalia women were 'more powerful at the grassroots level as organisers. They were the ones responsible for ..., critical economic forces, the material support, the moral support' (M. Derrie, male, $16 / 02 / 2011$ ). These women organised the civilians in Somalia and in the Ogaden to help and support the joint Somali forces, setting up initiatives that could provide the fighting forces with everything they needed. "[S]ince the women are attractive to the public, comparing with men ... they have an easy access to mobilising the community. To contact with them, to persuade them the visions, the agenda's and [mobilising] the whole communities in the Ogaden' (Volunteer, female, I9/02/201r). Thus many Somali civilian women put a lot of effort into supporting the Somali troops, especially the WSLF. A current member of the Ogaden National Liberation Front or ONLF explained how social organisations helped to organize their actions:

'When we come back to the social groups and their role in the struggle, the leading roles where [...] to the Youth League and ... the women group of the WSLF ... [led] by a madam called Fadimah Hasan. ... [A]nd they participated in two ways: the first was that of the mobilisation, the moral support ... as [in] a campaign. And the other one was through the military. Those two perspectives, the women participated in the conflict. ... And from that perspective, the women were the backbone, the only column that the whole struggle was circling through. ... The other group who were very active in the struggle were the youth group who were consisted of [both] boy and girls, but ... particular ... the women group called "The Mothers" [Hooyooyin]. The Mothers, they had the good role because of they were even influential to the Somalian Government to support the Ogaden struggle, I mean the Western Somali struggle at that time ... And ... some ... visited the battlefield of the Ogaden in 1977. [They] were above 70 per cent the Mothers, or the women was to work toward equality for Somali women. With the socialist revolution in 1969 , women were encouraged to attend school beyond the elementary level and to participate in government and the military. The Family Law (Xeer Qoyska) of 1975 sought to establish women's equality in several areas.' (Merryman,1996). 
group, who physically went there and saw what is happening, and they come back Somalia and according to their observations, mobilised the community, to the Ogaden war of the 1977' (M. Sherif, male, 27/04/20II).

One of these Hooyooyin explained how they organised themselves and how they helped the WSLF in its struggle in the Ogaden:

'A number of elderly women belonging to the Ogaden people, we used to collect the money from per person. We used to make ropes and ties and ... the [ammunition holder]. We used to buy the military dress, the shoes, the belts, and even the ... drink can. We were a number of mothers, then, when we paid the whole necessities, the dresses, the robes, the belts. [Y]ounger girls ... bring [all this] to Ogaden, from Mogadishu' (Volunteer, female, 19/02/201I).

Yet some of these women felt they had to do more and went into the Ogaden in the midst of the war. During the months in which Somalia and the WSLF had control of the Ogaden (roughly between July 1977 and the beginning of 1978 ) it was safe for Somalis to enter this region. The same Hooyo (mother), for example, went to support her husband who was fighting as a military commander. In the Ogaden she mainly took care of lightly wounded fighters:

'At the time, the, most of the rebels were at the frontline. ... those [who] got injured, mostly they were taken directly to Somalia. But some of them were brought to us, and we provided the food, the medicine, [but] they were smaller number. Most of them was directly taken to Somalia' (Volunteer, female, I9/02/2011).

Most of the people this volunteer treated were men, but sometimes a woman would be in need of help as well. Not only were the injured treated by volunteers, the medicines they received were also paid for by these people: the Somali government only paid for those soldiers who needed to be transferred to Somalia (Ibid.). The dedication of many of the Somali civilians to the Ogadeni or Western Somali cause can be seen as evidence of a solidarity system built around political beliefs rather than clan or family focused care. People were rallied behind a nationalist cause that transcended clan lines, donating for both the fighters and victims of a conflict that was never really in the interest of their own clan.

Women were also important in Somali politics. Some, such as Mrs. Dahab Omar Mohamed, held important functions, ${ }^{9}$ yet women were primarily a powerful pressure group. In a CNN documentary on the Cold War it is clear that women were not only present during political rallies and protests but they were also very active during such events. ${ }^{10} \mathrm{~A}$ former journalist confirmed this, noting that whenever a political meeting

9 She was a Somali diplomat in Tanzania [ 'Somalia holding our land, admits Ethiopia' 04/081977].

Io http://www.youtube.com/watch?v=inRpIPRgmdo\&feature=realted Turned T. 'CNN Cold War (17) Good Guys Bad Guys. 1967-1978' (consulted on 22-07-2011, 09u27). 
took place, there were always a lot of women present. Many of these women were members of the Somali Women's League, cheering and taking part in the discussions:

'Siad Barre was addressing a rally in central Somali in a place, that town called Jowhaar. ... Calling for the people to support their soldiers in the front. Now the women delegation there told him: "No worry about Kenya: we, the women, will take care of Kenya, you need to concentrate on Ethiopia."... It was on the radio. Quite an insult! To Kenya, isn't it?' (M. Warsama, male, 15/03/2011).

The fighters, nurses, logistic helpers, and Hooyooyin had one thing in common: they themselves had chosen to become involved in the war. It is certainly the case that ' $[\mathrm{i}] \mathrm{t}$ is hard to make generalizations about female soldiers given their small number and heterogeneity' (Reséndez Fuentes, 1995), but since women were not enrolled as soldiers in the army, those who did pick up a gun and fight did so of their own free will. Those leaving their jobs in Somalia to enter the Ogaden and serve as a nurse or volunteer in the WSLF did so because they wanted to help. These women had to have a clear vision of politics and society, putting aside social and religious conventions and mockery of friends (M. Derrie \& Ugas, both male, $16 / 02 / 2011)$. Therefore the devotion of these women towards the cause of the war (whether it be an independent Ogadeenia or a Greater Somalia) could be as strong as the devotion of men (Ibid). When the war was over, everybody knew who had been active at the front with the WSLF. This means that female fighters, like their male colleagues, can never return to Ethiopia, but also that they received a lot of respect within the Ogadeeni and Somali society (cf. infra) (Fadumo M., female, 12/03/201r).

While the women described here committed themselves to the war as a fighter, nurse or volunteer, many others were forced to support one of the fighting parties. Ogadeeni women gave Somali fighters provisions, occasionally in the form of livestock (M. Derrie \& Ugas, both male, $16 / 02 / 2011$ ). However, the WSLF sometimes had to use force to obtain these goods: for many different reasons not all people supported the WSLF and its struggle. Their unclear position with respect to Ogadeeni independence made some people believe the WSLF was a puppet army of the Somali regime (H. Isse, male, I4/03/20Ir).

\section{Women in the SNM and ONLF}

After the Ogaden war, women remained important in the military facets of Somali life. They were, for example, active in units of the Somali National Movement (SNM) that was fighting Siad Barre from 1982 until he was ousted in I991 (Bradbury, 2008). In the first years of their fight (i.e. before 1988 ) women in the SNM predominantly held roles as carers. Their role then was to 'protect and provide for the family, assist jailed relatives and fundraise' (Ibid.). When the SNM gained more popular support however, women organised themselves and also participated in the struggle as fighters, front-line nurses, cooks, and paramedics (Ibid.).

Women were equally involved in the long transition from WSLF to the Ogaden $\mathrm{Na}$ tional Liberation Front (ONLF). Zamzam (female 20/02/2011), for example, joined the 
Western Somali Youth Organisation ${ }^{11}$, the youth wing of the Western Somali Liberation Front and she became a member of the executive committee of the Student Congress. The youth wing was based in Somalia and participated in conferences all over the country and even in conferences of the Arab League. Many women were involved in this organisation, even at the higher levels (I. Asayr, female, 20/02/20II). Soon, however, a conflict between the WSLF and its more radical youth wing arose on political matters concerning Ogaden autonomy. This led, in 1984 , to the arrest of the Chairman, the vice chair, the secretary, and a few other important members, including Zamzam. After this episode the Western Somali youth league made an important decision: the name of the organisation was changed: Western Somalia was substituted by Ogaden (M. Sherif, male, 27/04/20II; Zamzam, female, 20/02/201I). From now on, the independence of the Ogaden region was their main goal and the idea of a Greater Somalia was abandoned. Zamzam explains how she was involved in these events:

'I was in that committee [of the Western Somali Youth Organisation] for 4 years. In those years, I helped to reform the movement to the ONLF. We saw it as the only solution of the struggle. The name change was widely appreciated among the people, but nobody dared to change it thus far. ... the organisation was big enough to pressure the regime. [The] call for independence of the Ogaden, through the symbolic change of the name, did thus not pass unnoticed.' (Zamzam, female, 20/02/2011).

The Somali government and the WSLF subsequently turned against this new liberation front that was no longer aiming to incorporate the Ogaden into Somalia and tried to disrupt and disorganise the ONLF (Ibid).

Today, many women are fighting in the Ogaden for the ONLF. These women were mainly pushed into the ONLF by circumstances. A young woman told the news agency Aljazeera that 'The Ethiopian troops imprisoned me and my brother. They killed him in front of my eyes and then they raped me. They killed my husband as well. Seeking security, I joined the fighters.'12 Many others, too, want to protect themselves by acquiring a gun and joining the rebels (H. Isse, male, 14/03/2011). Those who join the ONLF have to be trained: some girls say they were trained for a couple of years, others claim they were trained in just over a month (Liilaaf, female, I7/02/20II; H. Isse, male, I4/03/201I).

For Ogaden women soldiers, the role of guerrilla is a difficult additional load to bear, next to running a household, raising children and tending the cattle. While women engaged in activities usually not related to their gendered position in societies, their behaviour is not matched by Ogadeni men who are fighting in - or fleeing from - the war, without taking up any of the household roles usually performed by women. ${ }^{13}$ Thus, the

II This organisation was established on 13 July 1979 (M. Sherif, male, 27/04/2011).

12 Broadcast from Aljazeera, 16/04/2008. The girl's statement was dubbed in English, it is this text I used here. [http://www.youtube.com/watch?v=OOrjflVaBoE consulted on 13-01-2010: 10u12].

13 Broadcast from Aljazeera, 16/04/2008. The girl's statement was dubbed in English, it is this text I used here. [http://www.youtube.com/watch?v=OOrjflVaBoE consulted on 13-01-2010: 10u12]. 
burden of doubling gender roles lies solely with Ogadeni women. It is no surprise perhaps that a small number of women leave their family and household to join the rebels: they divorce their husband, leave their children with a relative and start anew in the bush with the rebels (H. Isse, male, $14 / 03 / 2011)$. These women receive a lot of support from those devoted to the 'Ogadeeni cause': 'Yes: being a member [of the ONLF] resulted in more respect. We received a lot of moral support from others' (Zamzam and I. Asayr, both female, 20/02/201I).

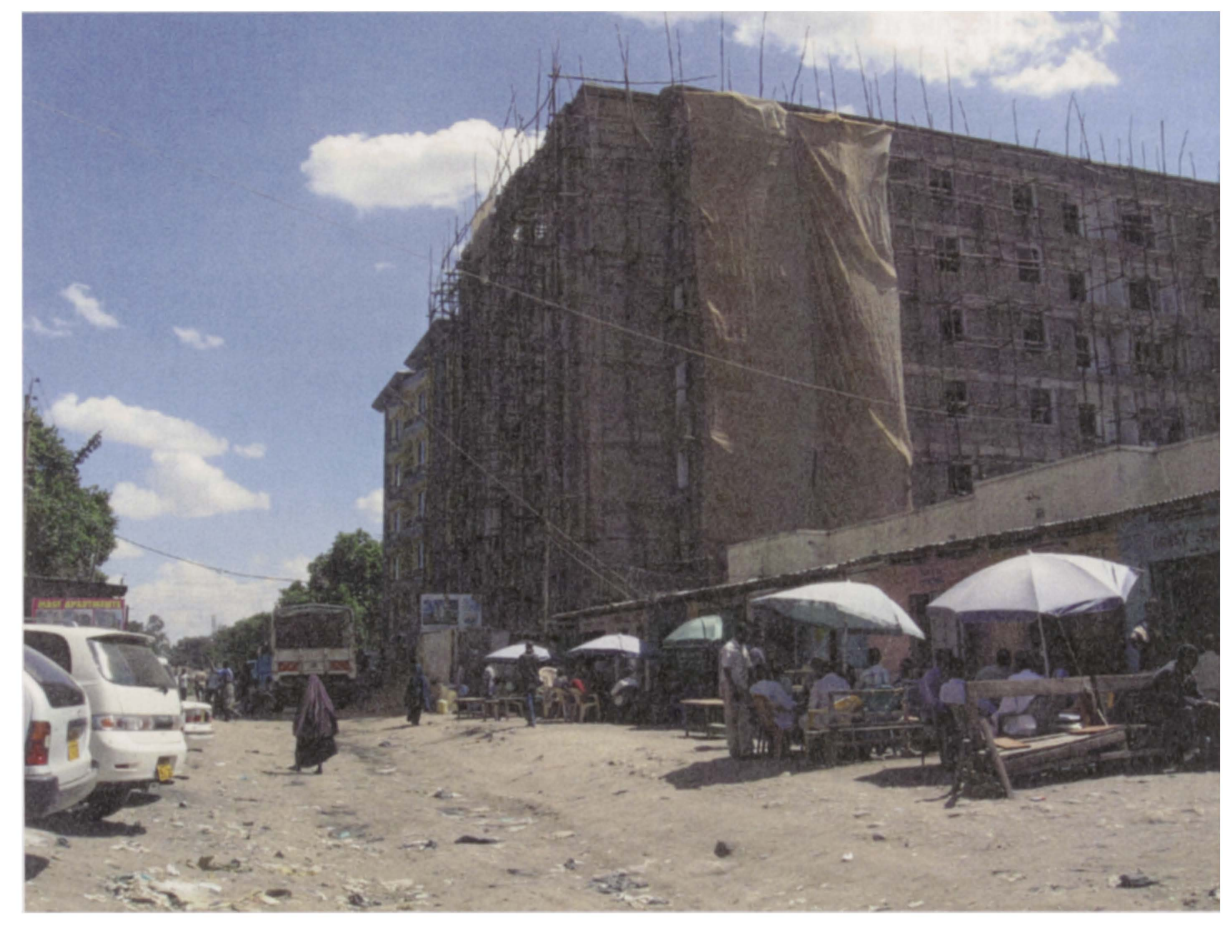

Figure 3: Somali men drinking tea in Easleigh (Josje Beukema)

\section{Perceptions and reactions}

Women thus played many different roles during the Ogaden war, and those women who took up active roles claim to receive respect for it. Yet, it needs to be said that most of the roles described above differ from the classic roles women play in Somali society (Gardner \& El Bushra, 2004). Therefore, not everybody was pleased with women fighting on different fronts of the Ogadeeni struggle, especially when women left their families in order to join the rebels. Those male respondents talking about female fighters with vigour and pride where therefore often very sympathetic to the Ogaden cause, interpreting their actions as the ultimate sacrifice to the Ogadeeni community $(\mathrm{H}$. Isse, male, 14/03/201I). For the ONLF, their female members prove, more than anything else, that their movement is ultimately rooted in the people (M. Sherif, male, 27/04/201I). Thus, 
the respect these women receive (both those active in the WSLF in the r970s as well as those active in the ONLF today) is often coupled to the political cause they served. This implies that people who hold other priorities are probably less likely to show former female fighters of the WSLF the respect these claim to receive. In this way, religious issues (always an important part of a society and its gendered roles) sometimes obstruct support for female fighters:

'Actually, in the ... Muslim religion ... they [women] can fight. Because ... if she has an [occupation] for herself, her family, own territory, own whatever, and when it's easy to rape, she is trying to defend herself. Because she can fight. Then, some of ... the cleric they say that "No! ONLF they doing like the western culture"... And ONLF ... announced "Yes, even the holy Q'ran and the Hadith, they are talking about ... generation to generation, there was fighting. And they are talking about some of the [women's] dress ... [but] if they stay in the town or she gets covered in the Hijab and one Ethiopian soldier comes to her and [it's] easy to kill, easy to rape [her] ... she has to go out to survive and stay wherever she can, trying to fight." It's easy! But most of them as in Ogaden region, from generation to generation, they know [this]. Even the ladies from that time [the Ogaden war] with the fighters, they support it. ... I saw some pictures they get the training and they go to fighters in the 1977.' (H. Isse, male, 14/03/20Ir).

One of the best illustrations of the fact that military women are not completely accepted, or even seen as a curiosity, is the story of Qasad and Hasan. They met while fighting on the frontline in the Somali-Ethiopian war, as members of the WSLF. Both were strong supporters of the Ogaden cause. They fell in love at the front and went to Somalia together to marry in Mogadishu. At the wedding many people joked about the fact Qasad had been, and still was, a fighter for the WSLF:

'His family they say "hey! The lady who is still fighting as a soldier, they look like the men. Are you married to another man?" [Laughs] Yes! But they think like that. This lady, she comes like a man. She is ... fighting and she is stronger than another woman, she is carrying the gun and everything.' (H. Isse, male, 14/03/2011).

Western academics and aid organisations, too, tend to hold the kind of inflexible gender perspectives that consign female fighters to the margins. Although terms such as 'gender' and 'empowerment' are enthusiastically used in their official communication, their perspectives are based on their idealised construct of Somali society. A more detailed knowledge of gendered power relations within a society would help to understand the processes at work today (Laplantine, 1978). With the aid industry so dominant in the Horn of Africa, it is no surprise that Somali women who efface gender roles are ignored (Kumar, 200r and Horst, 2006). 
'The idea hat [women] may be fighters as well as victims challenges the black and white ideas of conflict in Africa many in the West hold. As such, the image is intentionally or subconsciously repressed, much to the detriment of the empowerment of women that many in the West claim to advocate.' (Macdonald, 2008).

The image of a strong woman serving as a female fighter thus remained something unusual, thus those women engaged in warfare clearly break with conventional gender models of Somali society. Though gender roles do not disappear in wartime, violence and the created opportunities for women during conflicts can sometimes transform masculinities, femininities, and the relations between the sexes (Canning, 2006), or, as Nina Hall (2009) puts it:

'It is well documented in gender and politics scholarship that international and civil conflict transforms women's traditional roles and responsibilities, increasing their participation in politics and the paid labour force... After the conflict however there is often pressure on women to return to gender roles as they were pre-conflict.'

This idea is backed by the fact that the distinction between battlefield (presumed as 'male') and homestead (presumed as 'female') blurred when armies ploughed through villages or when guerrillas used towns as military bases. Whether such changes have occurred - and were maintained - in Somali society at large and whether these new images are conservative (and thus imply a more rigorous following of older gender roles) or progressive (and thus more flexible version of the original roles) is difficult to assess since the war-situation is not yet over. ${ }^{14}$ One could argue that the new and sometimes violent roles for Somali women are temporary since some of these women did not fight for (political) ideals but because they had no choice in the matter:

'Even though I was not there at that time, but I have seen a lot of women now, a lot of women say that "we have been taking part in the war ... as nurses, and at the same time helping other soldiers". Some of them were also fighting, having guns sometimes but, because these people were displaced, there is no other way that they can leave. They have to take part in the war. ... And it's not rare to see women participating in the war because if they are desperate, there is no other way that they can live. They have to take part in the war. Yeah, I know a lot of women who had taken part in that war.' (Civil Servant, male, 02/04/2011).

However, I believe Somali women have been so active over the last 50 years that a setback in women's participation in society will be difficult both for the women involved and for society at large. Mark Bradbury (2008) also described that the participation of women in the struggle for independence of Somaliland 'helped to alter social attitudes towards women.' Perhaps the female fighters in East Timor could be taken as an example for

14 Changes in gender relations were noticed during the Somali civil war of the 1990's. (Gardner \& El Bushra, 2004). 
Somali society, for here 'women have been able to transform from freedom fighters to a fully fledged women's movement within the short space of a decade' (Hall, 2009).

\section{Conclusion}

This paper has sought to 'flesh out' an aspect of the still skeletal history of the Ogaden war and the even thinner herstory of Somali women. The narrative above brings both a new image of the roles women played in the Ogaden war and new insight into the sorts of roles these women took up. Like women elsewhere in the world, Somali women seem to have been much more influential in this conflict than previously portrayed. Women were fighters, nurses, communication experts, cooks, drivers, lobbyists, recruiters, politicians, military leaders, carriers, demonstrators etc. After the Ogaden war, women did not retreat from conflicts: many joined the SNM and ONLF, performing similar roles. And it is not only women who occupy remarkable roles (those involving violence and/or leadership) who are confirming the agency women can have in Somali society, but also those with roles more congruent with the prevalent gender roles, such as nurses or cooks - they, too, mark a shift in gender patterns. This variety of roles and the fact that some of these roles might be associated with male gender roles might surprise many people with a superficial knowledge of Somali Muslim society. Yet it is important to restate that existing gender roles in a society, while they can become more flexible in wartime, will not disappear (Canning, 2006). This explains why the Somali public generally accepted women involved in the conflict for they knew these were exceptional circumstances, even though some of women's roles were problematic for some conservative forces. It also explains the humorous remarks people made at the wedding of Hasan and his wife Qasad: after all, strong women occupying tough positions were still considered to be peculiar. Furthermore those 'westerners' active in the Horn of Africa today should take into account the findings of more precise and localised gender studies to contextualize their theories and practices in situ. This is especially true for those conflicts in the region where female fighters are also responsible for hardship and suffering.

A number of remarkable issues that merit the attention of scholars appeared in the margins of this paper. First, the danta emerged as a cultural phenomenon that could give us more insight on how group identity is formed in Somali societies. Extensive research on these dances can provide us with information on the positions of men, women, civilians and fighters within their society, and how power relations either hold these positions in place or alter them. Second, the solidarity of (amongst others) the Hooyooyin sheds new light on rigid notions of Somali solidarity found in academic literature. During the Ogaden war, Somali nationalism seemed to have eclipsed clan structures, making new and critical research on solidarity in Somali society a possibility. Third, research on sexual violence during the Ogaden war is necessary in order to deepen our understanding of the impact of the conflict. Without downplaying the cruelty of sexual violence, such research should not view Somali women solely through the lense of victimhood, but keep in mind the complexity of women's agency in Somali society. 
Finally, it is clear that 'the consequences of the 1977's war are still visible up until today' (L., female, 17/02/2011). The women active in the Somali-Ethiopian war lost friends and relatives, they witnessed killings and war wounds, they were raped, lost their homes and livelihood, they feared for their lives and for the lives of those around them - in short they lived in a state of constant anxiety and insecurity. Their male friends and companions obviously went through similar situations. In other words, it is important to remember that wars predominantly create victims and these victims are both men and women. Finally, regardless of the strengths women displayed in the Somali-Ethiopian war, such as their ferocity and bravery in combat, many women died in the war and in the eyes of many, women are in the first place still victims of war (M. Ali, male, I4/03/20II). Wars can create opportunities for women, enabling them to cross borders erected by others, but even these opportunities are gendered: 'Some women, certainly, are strong. But ... it seems ... clear that women's goals themselves are shaped by social systems which deny them ready access to the social privilege, authority, and esteem enjoyed by a majority of men' (Rosaldo, 1980).

\section{Acknowledgements}

I am grateful to Baz Lecocq and Marleen Renders for their valuable remarks on this text. I would also like to thank Axmed, Gure and Hassan who served as interpreters during my interviews. Research in Kenya was supported by a travel grant from VLIR-UOS.

\section{References}

Abdullahi, M. (200I). Culture and Customs of Somalia Westport, 198 p.

Amnesty International, (1991). Ethiopia: End of an era of brutal repression - a new chance for human rights London, $57 \mathrm{p}$.

Bradbury, M. (2008). 'Becoming Somaliland'. In African Issues, Oxford-Nairobi, 271 p.

Brett, R., Specht I. (2004). Young Soldiers. Why They Choose to Fight. Boulder, $192 \mathrm{p}$.

Canning, K. (2006). 'Gender History. Meanings, Methods \& Narratives' In Canning K., Gender History in Practice, Historical Perspectives on Bodies, Class \& Citizenship, London, p. 3-62.

Cerulli, E. (1957). Somalia. Scritti vari editi ed inediti. I: Storia della Somalia. L'slam in Somalia. Il Libro Degli Zengi, Rome, $363 \mathrm{p}$.

De Beauvoir, S. (1979). The Second Sex (Translated by Parshley H.M.) Harmondsworth, 762 p.

El-Bushra, J., Sahl, I.M.G. (2005). Cycles of Violence. Gender Relations and Armed Conflict, Nairobi, i69 p.

Gardner, J., El Bushra, J. (eds.) (2004). Somalia - The Untold Story. The war through the eyes of Somali women, London, $257 \mathrm{p}$.

Haeri, S. (1995). 'The Politics of Dishonor: Rape and Power in Pakistan.' In Afkhami M. Faith \& Freedom. Women's Human Rights in the Muslim World, London, pp. I6I-174.

Hall, N. (2009). 'East Timorese Women Challenge Domestic Violence'. In Australian Journal of Political Science Vol. 44, No. 2, June 2009, pp. 309-325.

Heirman, M. (ed.) (s.d.) 'Regionale konflikten en internationale spanningen in de Hoorn van Afrika'. In International Peace Information Service - Dossiers Antwerp, $96 \mathrm{p}$.

Horst, C. (2006). 'Transitional Nomads. How Somalis cope with refugee life in the Dadaab camps of Kenya'. In Castles, S. \& Chatty, D. (2006), Studies in Forced Migration, Vol. 19: Oxford, 236 p.

Jama, M.Z. (1991). 'Fighting to Be Heard: Somali Women's Poetry'. In African Languages and Cultures, Vol. 4, No. I, The Literatures of War, pp. 43-44.

Kumar, K. (ed.) (200I). Women \& Civil War. Impact, Organization, and Action, Boulder, 253p. 
Laplantine, F. (1976). 'Maladies mentales et thérapies traditionnelles en Afrique Noire'. In Delarge J.-P (ed.), (1976) Encyclopedie universitaire Paris, $156 \mathrm{p}$.

Lockyer, A. (2006). Opposing Foreign Intervention's Impact on the Course of Civil Wars: the Ethiopian-Ogaden Civil War, 1976-1980. Refereed paper presented at the Australasian Political Studies Association Conference (University of Newcastle), 25-27 September 2006.

Macdonald, A. (2008). 'New Wars: Forgotten Warriors': Why Have Girl Fighters Been Excluded from Western Representations of Conflict in Sierra Leone?'. In: Africa Development. Vol. 33, No. 3 (2008) pp. 135 -I45.

Mazurana, D., Raven-Roberts, A., Parpart J. (2005). Gender, conflict, and peacekeeping. Oxford, 304 p.

Merryman, N.H. (1996). 'Women's Welfare in the Jubba Valley: Somali Socialism and After'. In Besteman C. and Cassanelli L.V. (1996). The Struggle for Land in Southern Somalia. The War Behind the War, London, pp. 179-198.

Monitoring Group on Somalia pursuant to Security Council resolution 1853 , (2008) (2010). Report of the Monitoring Group on Somalia pursuant to Security Council resolution 1853 (2008). New York (http://www. un.org/ga/search/view_doc.asp?symbol=S/2010/91, consulted on I-03-2012, 16uor).

Morgan, R. (ed.) (1970). Sisterhood is Powerful: An Anthology of Writings from the Women's Liberation Movement. Random House, $602 \mathrm{p}$.

Okin, S.M. (1998). 'Gender, the public, and the private'. In Phillips A. (1998). Feminism \& politics, Oxford, pp. II6-I4I.

Page, M. (1998). KAR. A History of the King's African Rifles and East African Forces, London, 298 p.

Reséndez Fuentes, A. (1995). 'Battleground Women: Soldaderas and Female Soldiers in the Mexican Revolution'. In: The Americas Vol. 51, Nr. 4 (April), pp. 525-553.

Riley, D. (1987). 'Does a Sex have a History? 'Women' and Feminism'. In New Formations, nr. I (Spring 1987), pp. 35-45.

Rivelli, F. (ed.) (2010). A situation analysis of mental health in Somalia World Health Organisation, 62 p.

Rosaldo, M.Z. (1980). 'The Use and Abuse of Anthropology: Reflections on Feminism and Cross-Cultural Understanding'. In Signs Vol. 5, No. 3, p. 393-396 Scott J.W. (1986). 'Gender: a Useful Category of Historical Analysis'. In The American Historical Review, Vol. 91, nr. 5, (Dec. 1986), pp. 1053-1075.

- (2008). 'Unanswered Questions'. In American Historical Review, Vol. I13, nr. 5, (December 2008), pp. 1422-1429.

Tareke, G. (2000). 'The Ethiopia-Somalia War of 1977 Revisited'. In The International Journal of African Historical Studies, Vol. 33, No. 3, pp. 635-667.

Wiesner-Hanks, M. (2008). Women and Gender in Early Modern Europe. Third Edition, Cambridge, $340 \mathrm{p}$.

Young, A. (198I). 'The United States and Africa: victory for diplomacy'. In Foreign Affairs, America and the world. 1980 , Vol. 59, nr. 3, pp. 648-666.

\section{Newspapers}

Duffy, J.M. (02 June 1977 ). 'Eritrean Rebels Think They Scent Victory'. In The New York Times, p. A 8 (Late City Edition).

S.n. (18 August 1977). 'Ogaden people to decide'. In Daily Nation, p. I.

S.n. 'Confrontatie in de Ogaden'. In Keesings Historisch Archief. 1977. (year 46, No. 2402), p. 6rI.

S.n. (24 October 1977).'Sticks, Stones and Rockets'. In Time magazine on http://www.time.com/time/magazine/article/0,9171,915678,00.html\#ixzzIS5apxNsC.

S.n. (04 August 1977 ). 'Somalia holding our land, admits Ethiopia'. In Daily Nation, p. 6. 


\section{Video}

Turned, T. 'CNN Cold War (17) 'Good Guys Bad Guys. 1967-1978' on www.youtube.com/watch?v=inRpIPR 9mdo\&feature=realted (consulted on 22-07-2011, 09u27).

Broadcast from Aljazeera, $\mathrm{I} 6 / 04 / 2008$. The girl's statement was dubbed in English, it is this text I used here. [http://www.youtube.com/watch?v=OOrjflVaBoE consulted on I3-0I-2010: Iour2]

\section{Lectures}

Rosi Braidotti (07 March 2012) 'Writing and being written by Nomadic Subjects?'. Lecture at Ghent University. 